ISSN 0258-7122 (Print), 2408-8293 (Online)

Bangladesh J. Agril. Res. 41(4): 675-684, December 2016

\title{
USE OF ORGANIC AMENDMENT FOR MANAGEMENT OF FUSARIUM WILT OF GLADIOLUS
}

\author{
L. YASMIN ${ }^{1}$ AND M. A. ALI ${ }^{2}$
}

\begin{abstract}
The experiment was conducted at Horticulture Research Centre (HRC), Bangladesh Agricultural Research Institute (BARI), Joydebpur, Gazipur during 2009-2011 following RCB design with four replications. Eight soil amendments such as Poultry refuse $\left(5 \mathrm{t} \mathrm{ha}^{-1}\right)$, Mustard oil cake $\left(600 \mathrm{~kg} \mathrm{ha}^{-1}\right)$, Sesbania rostrata $\left(5 \mathrm{t} \mathrm{ha}^{-1}\right)$, Municipal waste compost $\left(5 \mathrm{t} \mathrm{ha}^{-1}\right)$, BARI Trico- compost ( $2 \mathrm{t}$ $\left.\mathrm{ha}^{-1}\right)$, Leachate $\left(200 \mathrm{ml} \mathrm{m}^{-2}\right)$ were evaluated against Fusarium wilt of gladiolus caused by Fusarium oxysporum f. sp. gladioli under field condition. Poultry refuse was very effective in inhibiting the disease resulting maximum germination $(99.98 \%)$, spike length $(73.90 \mathrm{~cm})$, rachis length $(43.70 \mathrm{~cm})$, florets spike $^{-1}$ (12.63), flower sticks plot ${ }^{-1}$ (38.75) and corm plot ${ }^{-1}(60.23)$ and cormel yield ha ${ }^{-1}(2.51 \mathrm{t})$. Mustard oil cake, BARI Trico-compost and Sesbania rostrata compost were also effective in inhibiting the disease and resulting better spike length, rachis length, florets spike ${ }^{-1}$, flower sticks plot $^{-1}$ and corm plot ${ }^{-1}$ and cormel yield.
\end{abstract}

Keywords: Gladiolus, Fusarium oxysporum, Fusarium wilt, Poultry refuse, Mustard oil cake, BARI Trico- compost

\section{Introduction}

The flower of gladiolus (Gladiolus sp.) is very popular and grown throughout the world in a wide range of climatic conditions. Gladiolus occupies fourth position in the international cut-flower trade (Misra and Singh, 1998). Gladiolus is also one of the most popular commercial flower in Bangladesh. The agro-ecological conditions of the country are very conducive for the survival and culture of gladiolus. But there is no authentic report on the statistics of area under cultivation of this crop. The major production belts of this flower are Jessore sadar, Sharsha, Jhikargacha,

Kushtia, Chuadanga, Satkhira, Khulna, Chittagong, Mymensingh, Dhaka, Savar and Gazipur. It has great economic value as a cut-flower and its cultivation is relatively easy. Income from gladiolus flower production is six times higher than that of rice (Momin, 2006).

${ }^{1}$ Senior Scientific Officer, Horticulture Research Centre, Bangladesh Agricultural Research Institute (BARI), Joydebpur, Gazipur 1701, ${ }^{2}$ Professor, Department of Plant Pathology, Bangladesh Agricultural University (BAU), Mymensingh, Bangladesh. 
The major obstacle for cultivation of gladiolus in Subtropical and Mediterranean regions is the various diseases caused by fungi, bacteria and viruses of which Fusarium wilt disease caused by $F$. oxysporum f. sp. gladioli is a major problem in all over the gladiolus growing areas. Fusarium wilt of gladiolus is considered as a serious and highly devastating disease which can cause $60-70 \%$ yield loss (Vlasova and Shitan, 1974) and the damage may reach upto 100\% (Pathania and Misra, 2000). Crop loss of $30 \%$ in Germany and $60-80 \%$ in Russia was estimated due to Fusarium wilt of gladiolus (Bruhn, 1955). It is also a serious problem in India and reduced plant growth and flowering upto $15-28 \%$ in the number of florets/spike (Misra et al., 2003).

The pathogen is both seed and soil borne. It causes curving, blending, arching, stunting, yellowing and drying of leaves associated with root and corm rot in the field as well as in the storage. F. oxysporum $\mathrm{f}$. sp. gladioli causes three types of rot e.g. vascular corm rot, brown rot and basal rot (Partridge, 2003). Vascular rot is also called yellows and is characterized by a brown discoloration in the centre of the corm and extending into the flesh. The leaf symptoms start at the tip of the leaf blade and gradually spread all over the leaf blade. If the plant is infected at later stage, it produces weak or small florets. When the plant is infected at early stage and infection is severe, whole plant becomes dry and dies within few days (Misra and Singh, 1998).

F. oxysporum f. sp. gladioli is a soil borne pathogen. It can survive in soil for many days. Soil amendments with different organic matter play an important role to control the disease as well as to improve soil quality. It prevents environmental pollution associated with the use of chemical fertilizers and pesticides. Soil organic amendments are known to improve soil aeration, structure, drainage, moisture holding capacity, nutrient availability and microbial ecology (Davey, 1996). Organic amendments as poultry manure, bonemeal and soymeal significantly reduced population of soil borne plant pathogens (Lazarovits, 2001). Different plants like Sesbania rostrata is used as soil amendment to control corm rot of gladiolus caused by $F$. oxysporum f.sp. gladioli. The plant extracts are able to reduce the incidence of the diseases and incorporation of plant extract into the soil enhanced shoot length and biomass (Riaz et al., 2010). The objective of this present work is to find out the effect of soil amendment on Fusarium wilt of gladiolus.

\section{Materials and method}

The experiment was conducted at the Floriculture Field, Horticulture Research Centre (HRC) of Bangladesh Agricultural Research Institute (BARI), Joydebpur, Gazipur during the period of 2009-2011. The experiment was set up in previously Fusarium oxysporum infested soil. It was laid out in the Randomized 
Complete Block Design (RCBD) with four replications. Treatments were $\mathrm{T}_{1}=$ Poultry refuse (PR) @ $5 \mathrm{t} \mathrm{ha}^{-1}, \mathrm{~T}_{2}=$ Mustard oil cake (MOC) @ $600 \mathrm{~kg} \mathrm{ha}^{-1}, \mathrm{~T}_{3}=$ Saw dust @ 5tha 1 , T4 =Sesbania rostrata compost @ 5t ha ${ }^{-1}, \mathrm{~T}_{5}=$ Municipal waste compost @ 5t ha ${ }^{-1}, \mathrm{~T}_{6}=$ BARI Tricho-Compost @ 2t ha ${ }^{-1}, \mathrm{~T}_{7}=$ TrichoLeachate $200 \mathrm{ml} \mathrm{m}^{-2}$ and $\mathrm{T}_{8}=$ Control. The organic amendment viz., Poultry refuse (PR), Mustard oil cake (MOC), Sesbania rostrata compost, Municipal waste compost were incoporated in soil 25 days before and BARI TrichoCompost, Leachate, Sawdust burning were incorporated in soil before 5 days of seed sowing. The materials were mixed well with $12-15 \mathrm{~cm}$ top soil of the field.

The recommended dose of fertilizers cowdung @ 10t/ha, TSP @ 225kg/ha and MoP $190 \mathrm{~kg} / \mathrm{ha}$ were applied to the soil during land preparation and thoroughly mixed with the soil. Urea @ 200kg/ha was top dressed in two equal splits, one at the four leaf stage and another at spike initiation stage (Woltz, 1976).

The unit plot size was $1.25 \mathrm{~m} \times 1.6 \mathrm{~m}$. Spacing was maintained at $25 \mathrm{~cm}$ between the rows and $20 \mathrm{~cm}$ between the plants. Depth of planting of the corms was $6 \mathrm{~cm}$. Two adjacent unit plots were separated by $50 \mathrm{~cm}$ space, and there was $75 \mathrm{~cm}$ space between the blocks. Germination (\%), Plant height $(\mathrm{cm})$, Spike length $(\mathrm{cm})$, Rachis length $(\mathrm{cm})$, Florets spike ${ }^{-1}$, Flower stick weight $(\mathrm{g})$, Flower sticks plot $^{-1}$, Flower sticks ha ${ }^{-1}$, Pre-germination-corm rot (\%), Wilted plant (\%), Disease incidence (\%), Percent disease index (PDI), Corms hill ${ }^{-1}$, Corm yield, Cormels hill $^{-1}$ and Cormels yield (g) were rcorded. The disease incidence, disease index and wilted plant were calculated using following formula:

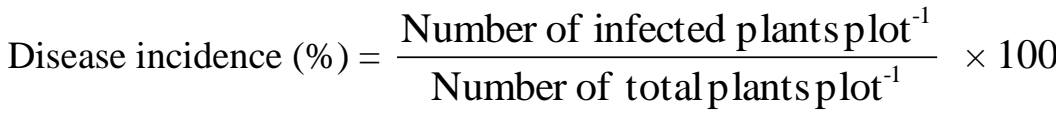

Percent disease index $(\%)=\frac{\text { Class frequency }}{\text { Total number of sample } x \text { Maximum grade of scale }} \times 100$

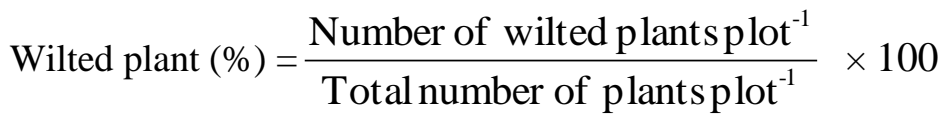

Data were analysed through MSTAT-C Software. Mean separation was done by DMRT at $5 \%$ probability level.

\section{Results and Discussion}

All the parameters of vegetative growth of gladiolus due to different types of soil amendments showed significant variations (Table 1). The maximum germination (99.98\%) was found in poultry refuse and BARI Trico compost amended plots and minimum corms (93\%) were germinated in control. 
Table 1. Effect of soil amendments on germination and vegetative growth of gladiolus

\begin{tabular}{lcc|c}
\hline \multicolumn{1}{c|}{ Treatments } & Germination (\%) & $\begin{array}{c}\text { Days to 50\% } \\
\text { germination }\end{array}$ & $\begin{array}{c}\text { Plant height } \\
(\mathrm{cm})\end{array}$ \\
\hline Poultry refuse (PR) & $99.98 \mathrm{a}$ & $17 \mathrm{~b}$ & $39.11 \mathrm{a}$ \\
& $(10.0)$ & & \\
Mustard oil cake (MOC) & $99 \mathrm{ab}$ & $20 \mathrm{a}$ & $38.57 \mathrm{ab}$ \\
& $(9.97)$ & & \\
Saw dust burning (SD) & $96 \mathrm{~d}$ & $20 \mathrm{a}$ & $37.72 \mathrm{bcd}$ \\
& $(9.8)$ & & \\
Sesbania rostrata compost (SRC) & $97 \mathrm{~cd}$ & $17 \mathrm{~b}$ & $38.28 \mathrm{abcd}$ \\
& $(9.8)$ & & \\
Municipal $\quad$ waste compost & $97 \mathrm{~cd}$ & $18 \mathrm{~b}$ & $37.42 \mathrm{~d}$ \\
(MWC) & $(9.8)$ & & \\
BARI Trico-compost (BTC) & $99.98 \mathrm{a}$ & $18 \mathrm{~b}$ & $37.49 \mathrm{~cd}$ \\
& $(10.0)$ & & \\
Leachate & $98 \mathrm{bc}$ & $17 \mathrm{~b}$ & $38.40 \mathrm{abc}$ \\
& $(9.12)$ & & \\
Control & $93 \mathrm{e}$ & $20 \mathrm{a}$ & $37.39 \mathrm{~d}$ \\
& $(9.62)$ & & \\
\hline CV\% & 0.41 & 3.98 & 1.56 \\
\hline
\end{tabular}

Means followed by the same letters in a column did not differ significantly by DMRT at the $5 \%$ level of probability.

About 17 days were required by the treatment of poultry refuse, Sesbania rostrata compost and leachate to 50\% corm germination while maximum (20) days needed in the treatment saw dust burning, mustard oil cake and control.

The plant height was $39.11 \mathrm{~cm}$ in poultry refuse which was identical to mustard oil cake, Sesbania rostrata and Leachate. The plants were comperatively short in control, municipal waste, BARI Trico-compost and sawdust.

Sharp variation was recorded on the pre-germination corm rot, severity (PDI) and wilted plant among different types of soil amendments (Table 2). The highest pre-germination corm rot $(8.0 \%)$ was recorded in control and minimum corm rot $(0.50 \%)$ was observed in the plot where poultry refuse and BARI Trico-compost $\left(\mathrm{T}_{6}\right)$ were used. The pre-germination corm rot ranged from $1.13 \%$ to $4.25 \%$ in other treatments. 
Table 2. Effect of different types of soil amendment on corm rot and Fusarium wilt of gladiolus

\begin{tabular}{c|c|c|c}
\hline Treatments & $\begin{array}{c}\text { Pre-germination } \\
\text { corm rot }(\%)\end{array}$ & $\begin{array}{c}\text { Disease severity } \\
(\text { PDI })\end{array}$ & Wilted plants $(\%)$ \\
\hline PR & $0.50 \mathrm{~d}$ & $26.25 \mathrm{~d}$ & $1.75 \mathrm{e}$ \\
& $(0.71)$ & $(29.73)$ & $(1.22)$ \\
MOC & $1.13 \mathrm{~d}$ & $27.5 \mathrm{c}$ & $3.02 \mathrm{~d}$ \\
& $(0.97)$ & $(30.50)$ & $(1.74)$ \\
SD & $4.25 \mathrm{~b}$ & $30.63 \mathrm{~b}$ & $6.98 \mathrm{ab}$ \\
& $(2.04)$ & $(32.40)$ & $(2.63)$ \\
SRC & $3.63 \mathrm{bc}$ & $28.13 \mathrm{c}$ & $4.36 \mathrm{~cd}$ \\
& $(1.89)$ & $(30.88)$ & $(2.07)$ \\
MWC & $3.63 \mathrm{bc}$ & $30.63 \mathrm{~b}$ & $6.30 \mathrm{bc}$ \\
& $(1.89)$ & $(32.40)$ & $(2.50)$ \\
BTC & $0.50 \mathrm{~d}$ & $27.5 \mathrm{c}$ & $3.63 \mathrm{~d}$ \\
& $(0.71)$ & $(30.50)$ & $(1.89)$ \\
Leachate & $2.38 \mathrm{c}$ & $28.13 \mathrm{c}$ & $6.22 \mathrm{bc}$ \\
& $(1.48)$ & $(30.88)$ & $(2.49)$ \\
Control & $8.00 \mathrm{a}$ & $33.13 \mathrm{a}$ & $9.71 \mathrm{a}$ \\
& $(283)$ & $(33.89)$ & $(3.11)$ \\
\hline CV\% & 17.10 & 1.35 & 15.03 \\
\hline
\end{tabular}

Means followed by the same letters in a column did not differ significantly by DMRT at the $5 \%$ level of probability.

Percent disease index (PDI) was maximum (33.13\%) in control plot and minimum $(26.25 \%)$ in soil amended by poultry refuse. Other treatments showed similar performance. The wilted plants were $9.71 \%$ in control plot, $1.75 \%$ in Poultry refuse and $3.02 \%$ to $6.98 \%$ in other plots.

Eighty eight days required for $50 \%$ spike initiation in Poultry refuse, Sesbania rostrata and Leachate. The effect of Municipal waste, Mustard oil cake and BARI Trico compost were similar. The maximum days (90) required for the control treatment to reach $50 \%$ spike initiation (Table 3 ). The poultry refuse produced the longest spike $(73.90 \mathrm{~cm})$ and the control plot gave the shortest spike $(66.68 \mathrm{~cm})$.

Poultry refuse and BARI Trico compost produced 12.63 florets spike ${ }^{-1}$. The number of florets spike ${ }^{-1}$ was 11.50 in sawdust followed by control. The weight of flower stick was $67.75 \mathrm{~g}$ in poultry refuse and $61.45 \mathrm{~g}$ in control. The range of stick weight of other treatments was $62.0 \mathrm{~g}$ to $66.90 \mathrm{~g}$. The higher number of 
flower sticks plot ${ }^{-1}$ was 38.75 in poultry refuse and lower number was 33.75 in control plot.

Table 3. Effect of soil amendments on flower characters of gladiolus

\begin{tabular}{c|l|c|c|c|c}
\hline Treatments & $\begin{array}{c}\text { Days to 50\% } \\
\text { spike } \\
\text { initiation }\end{array}$ & $\begin{array}{c}\text { Spike } \\
\text { length }(\mathrm{cm})\end{array}$ & $\begin{array}{c}\text { Florets } \\
\text { spike }^{-1}\end{array}$ & $\begin{array}{c}\text { Flower stick } \\
\text { weight }(\mathrm{g})\end{array}$ & $\begin{array}{c}\text { Flower sticks } \\
\text { plot }^{-1}\end{array}$ \\
\hline PR & $88 \mathrm{bc}$ & $73.90 \mathrm{a}$ & $12.63 \mathrm{a}$ & $67.75 \mathrm{a}$ & $38.75 \mathrm{a}$ \\
MOC & $89 \mathrm{abc}$ & $72.58 \mathrm{~b}$ & $12.38 \mathrm{ab}$ & $66.90 \mathrm{~b}$ & $38.50 \mathrm{ab}$ \\
SD & $90 \mathrm{a}$ & $67.54 \mathrm{f}$ & $11.50 \mathrm{c}$ & $62.00 \mathrm{e}$ & $34.75 \mathrm{e}$ \\
SRC & $88 \mathrm{c}$ & $71.63 \mathrm{c}$ & $12.38 \mathrm{ab}$ & $66.38 \mathrm{~b}$ & $37.50 \mathrm{c}$ \\
MWC & $89 \mathrm{abc}$ & $68.50 \mathrm{e}$ & $11.82 \mathrm{bc}$ & $62.75 \mathrm{~d}$ & $36.00 \mathrm{~d}$ \\
BTC & $89 \mathrm{abc}$ & $72.00 \mathrm{c}$ & $12.63 \mathrm{a}$ & $66.63 \mathrm{~b}$ & $38.00 \mathrm{bc}$ \\
Leachate & $88 \mathrm{bc}$ & $69.50 \mathrm{~d}$ & $11.83 \mathrm{bc}$ & $65.50 \mathrm{c}$ & $36.25 \mathrm{~d}$ \\
Control & $90 \mathrm{a}$ & $66.68 \mathrm{~g}$ & $11.53 \mathrm{c}$ & $61.45 \mathrm{e}$ & $33.75 \mathrm{f}$ \\
\hline CV\% & 1.11 & 0.55 & 3.34 & 0.71 & 1.28 \\
\hline
\end{tabular}

Means followed by the same letters in a column did not differ significantly by DMRT at the $5 \%$ level of probability.

The highest incidence of plant infection (69.25\%) was observed in control which produced the shortest rachis $(37.63 \mathrm{~cm})$ (Fig. 1). The lowest infection was recorded in soil amended by Poultry refuse $(54.50 \%)$ where longest rachis $43.70 \mathrm{~cm}$, number of flower sticks 92000 and corms $144,000 \mathrm{ha}^{-1}$ was produced Mustard oil cake also showed better performance as a soil amendment regarding disease incidence where rachis length was $42.50 \mathrm{~cm}$, number of flower sticks 91500 and corms $141,000 \mathrm{ha}^{-1}$.

Number of flower sticks, corms ha ${ }^{-1}$ and rachis length was minimum $(116,000)$ in control plots where plant infection was high.

Number of corms hill $^{-1}$ was insignificant among the treatments of soil amendment. Weight of individual corm varied significantly among the treatments where the weight $(17.75 \mathrm{~g})$ was maximum in Poultry refuse and minimum (14.83 $\mathrm{g})$ in control. Diameter of individual corm was comperatively large $(3.87 \mathrm{~cm})$ in Poultry refuse which was statistically similar to other treatments. Lowest diameter was $3.48 \mathrm{~cm}$ in control. Number of corm plot $^{-1}$ ranged from $53-60$ among the amended plots though control plot gave only 49 corms plot $^{-1}$. 


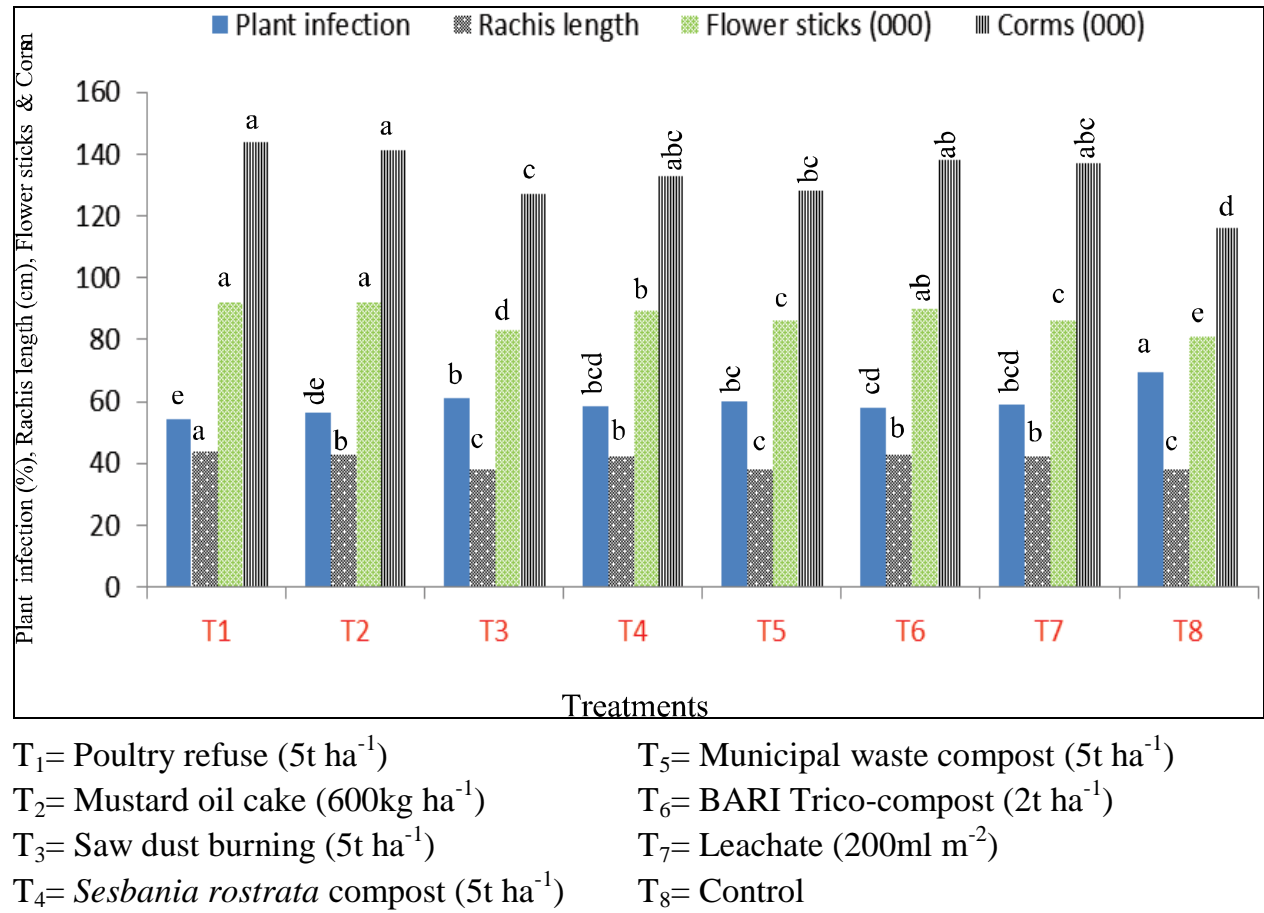

Fig. 1. Effect of different types of soil amendment on the plant infection (\%), rachis length $(\mathrm{cm})$, flower and corm $\left(\mathrm{ha}^{-1}\right)$ of gladiolus.

Table 4. Effect of different types of soil amendments on corm production of gladiolus

\begin{tabular}{c|c|c|c|c}
\hline Treatments & Corms hill $^{-1}$ & Corm weight $(\mathrm{g})$ & $\begin{array}{c}\text { Corm diameter } \\
(\mathrm{cm})\end{array}$ & ${\text { Corms } \text { plot }^{-1}}^{\text {PR }}$ \\
\hline POC & 1.53 & $17.75 \mathrm{a}$ & $3.87 \mathrm{a}$ & $60 \mathrm{a}$ \\
SD & 1.53 & $17.00 \mathrm{a}$ & $3.78 \mathrm{ab}$ & $59 \mathrm{a}$ \\
SRC & 1.48 & $15.25 \mathrm{~cd}$ & $3.58 \mathrm{bc}$ & $53 \mathrm{c}$ \\
MWC & 1.48 & $16.63 \mathrm{abc}$ & $3.76 \mathrm{ab}$ & $56 \mathrm{abc}$ \\
BTC & 1.50 & $15.45 \mathrm{bcd}$ & $3.60 \mathrm{bc}$ & $54 \mathrm{bc}$ \\
Leachate & 1.50 & $16.75 \mathrm{ab}$ & $3.75 \mathrm{ab}$ & $58 \mathrm{ab}$ \\
Control & 1.45 & $16.75 \mathrm{ab}$ & $3.64 \mathrm{abc}$ & $57 \mathrm{abc}$ \\
\hline CV\% & 5.34 & $14.83 \mathrm{~d}$ & $3.48 \mathrm{c}$ & $49 \mathrm{~d}$ \\
\hline
\end{tabular}

Means followed by the same letters in a column did not differ significantly by DMRT at the $5 \%$ level of probability. 
Significant variation was observed in cormel production of gladiolus by different types of soil amendments (Table 5). The number of cormels hill ${ }^{-1}$ was higher ( 22.13 ) in the Poultry refuse and lower (16.75) in control. Weight of cormels hill ${ }^{1}$ was $21.25 \mathrm{~g}$ in control plot which was enhanced in amended plots. The cormel yield plot ${ }^{-1}$ was $1053 \mathrm{~g}$ and yield $\mathrm{ha}^{-1}$ was $2.51 \mathrm{t}$ in Poultry refuse. BARI Trico compost produced cormel of $1008 \mathrm{~g} \mathrm{plot}^{-1}$ and $2.40 \mathrm{t} \mathrm{ha}^{-1}$, respectively. The other amended plots produced lower yield of cormel. Cormel yield plot $^{-1}$ and ha $^{-1}$ was $711 \mathrm{~g}$ and $1.70 \mathrm{t}$, respectively in control plots.

Table 5. Effect of different types of soil amendments on cormel production of gladiolus

\begin{tabular}{|c|c|c|c|c|}
\hline Treatments & Cormels hill $^{-1}$ & $\begin{array}{l}\text { Cormel weight } \\
\text { hill }^{-1}(\mathrm{~g})\end{array}$ & $\begin{array}{c}\text { Cormel yield } \\
\operatorname{plot}^{-1}(\mathrm{~g})\end{array}$ & $\begin{array}{c}\text { Cormel yield } \\
\mathrm{ha}^{-1}(\mathrm{t})\end{array}$ \\
\hline PR & $22.13 \mathrm{a}$ & $26.00 \mathrm{a}$ & $1053 \mathrm{a}$ & $2.51 \mathrm{a}$ \\
\hline MOC & $21.25 \mathrm{a}$ & $25.63 \mathrm{ab}$ & $994 \mathrm{a}$ & $2.37 \mathrm{a}$ \\
\hline $\mathrm{SD}$ & $18.00 \mathrm{bc}$ & $23.88 \mathrm{~b}$ & $860 \mathrm{c}$ & $2.05 \mathrm{c}$ \\
\hline SRC & $20.00 \mathrm{ab}$ & $26.10 \mathrm{a}$ & $972 a b$ & $2.32 \mathrm{ab}$ \\
\hline MWC & $19.50 \mathrm{ab}$ & $24.13 \mathrm{ab}$ & $881 \mathrm{bc}$ & $2.10 \mathrm{bc}$ \\
\hline BTC & $21.50 \mathrm{a}$ & $26.00 \mathrm{a}$ & $1008 \mathrm{a}$ & $2.40 \mathrm{a}$ \\
\hline Leachate & $19.75 \mathrm{ab}$ & $25.13 \mathrm{ab}$ & $855 \mathrm{c}$ & $2.04 \mathrm{c}$ \\
\hline Control & $16.75 \mathrm{c}$ & $21.25 \mathrm{c}$ & $711 \mathrm{~d}$ & $1.70 \mathrm{~d}$ \\
\hline CV\% & 8.90 & 4.89 & 7.79 & 7.75 \\
\hline
\end{tabular}

Means followed by the same letters in a column did not differ significantly by DMRT at the $5 \%$ level of probability.

Eight soil amendments such as Poultry refuse $\left(5 \mathrm{tha}^{-1}\right)$, Mustard oil cake (600 kg $\left.\mathrm{ha}^{-1}\right)$, Sesbania rostrata $\left(5 \mathrm{t} \mathrm{ha}^{-1}\right)$, Municipal waste compost $\left(5 \mathrm{t} \mathrm{ha}^{-1}\right)$, BARI Trico- compost $\left(2 \mathrm{t} \mathrm{ha}^{-1}\right)$, Leachate $\left(200 \mathrm{ml} \mathrm{m}^{-2}\right)$ were tested for controlling Fusarium wilt of gladiolus. Poultry refuse was very effective in inhibiting the disease resulting maximum germination $(99.98 \%)$, spike length $(73.90 \mathrm{~cm})$, rachis length $(43.70 \mathrm{~cm})$, florets spike ${ }^{-1}(12.63)$, flower sticks plot $^{-1}(38.75)$ and corm $\operatorname{plot}^{-1}(60.23)$ and comel yield ha ${ }^{-1}(2.51 \mathrm{t})$. Lazarovits (2001) found that poultry manure, meat and bone meal and soymeal significantly reduced population of soil-borne plant pathogen. Mustard oil cake and BARI Trico compost were also effective in inhibiting the disease and resulting better spike length, rachis length, florets spike ${ }^{-1}$, flower sticks plot $^{-1}$ and corm plot $^{-1}$ and comel yield. Sultana and Ghaffar (2010) reported that $F$. solani infested seeds of bottle gourd, cucumber and biter gourd reduced seedling mortality and root infection when sown in mustard and neem cake amended soil. Raj and Kapoor (1996) also reported that groundnut and mustard oil cake at $2 \%$ concentration of soil $(\mathrm{w} / \mathrm{w})$ were most effective in reducing pathogen population $(>70 \%)$ and 
disease incidence of Fusarium wilt of tomato. Mishra et al. (2004) reported that an isolate of Trichoderma virens significantly reduced the pathogen of corm rot and wilt of gladiolus. Walid et al. (2010) proved that T. harzianum was more efficient to control $F$. oxysporum f. sp. gladioli corm rot of gladiolus and enhanced plant growth, increased flower production and quality. Sesbania rostrata compost was also effective in inhibiting the disease. Riaz et al. (2010) reported the incorporation of leaves of some plant species significantly reduced the disease incidence and number of lesions on corms and enhanced shoot length and biomass.

\section{Conclusion}

Poultry refuse $\left(5 \mathrm{t} \mathrm{ha}^{-1}\right)$ was highly effective to combate Fusarium wilt of gladiolus resulting maximum germination, spike length, rachis length, florets spike $^{-1}$, flower sticks plot ${ }^{-1}$ and corm plot ${ }^{-1}$ and comel yield. Mustard oil cake and BARI Trico compost were also effective in inhibiting the disease and resulting quality flower of gladiolus.

\section{References}

Bruhn. 1955. Untersuchungen uber die Fusarium krankheit de gladiolen. Phytopathology, 25: $1-38$.

Davey, CB. (1996). Nursery soil management-organic amendments. In: Landis TD, Douth DB (Tech.Coordinators), National Proceedings, Forest and Conservation Nursery Associations. General Technical Report PNW-GTR-389, USDA Forest Service PNWRS, 6-18.

Lazarovits, G. 2001. Management of soil-borne plant pathogens with organic soil amendments : a disease control strategy salvaged from the past. Can. J. Plant Pathol., 23: 1-7.

Misra, R.L. and B. Sngh. 1998. Gladiolus. In: Commercial Flowers. (Eds) Bose, T. K. and L. P. Yadav. Naya Prokash, Calcutta, India. Pp. 266-353.

Misra, R.L., B. Sing and S.K. Palai. 2003. Galdiolus. In. Commercial Flowers. Vol-2. $2^{\text {nd }}$ Rev. ed. Nayaprokash. Calcutta, India. Pp. 1-113.

Mishra, P.K., A.N. Mukhopadhyay and U.S. Singh. 2004. Suppression of Fusarium oxysporum f. sp. gladioli populations in soil by application of Trichoderma virens and in vitro approaches for understanding biological control mechanisms. Indian Phytopathol., 57 (1): 44-47.

Momin, M.A. 2006. Floriculture Survey in Bangladesh. A Consultancy Report. FAO/ UNDP (IHNDP/BGD/97/06).

Pathania, N.S. and R.I. Misra. 2000. In vitro mutagenesis studies in gladiolus for induction of resistance to Fusarium oxysporum f. sp. gladioli. International Horticultural Congress: Elegant Science in Floriculture. Acta Horticulturae 624, 26. 
Partridge, J.E. 2003. Fusarium rot and yellows of gladiolus. Department of Plant Pathology, University of Nebraska, Lincoln, NE, USA, 47 P.

Riaz, T., S.N. Khan and A. Javaid. 2010. Management of Fusarium corm rot of gladiolus (Gladiolus grandiflorus sect. Blandus cv. Aarti) by using leaves of allelopathic plants. African J. Biotech. 9(30): 4681-4686.

Raj, H. and I.J. Kapoor. 1996. Effect of oil cake of soil on tomato wilt caused by Fusarium oxysporum f. sp. lycopersici Indian Phytopath. 49 (4): 355-361.

Sultana, N. and A. Ghaffar. 2010. Effect of fungicides, microbial antagonists and oil cakes in the control of Fusarium solani, the cause of seed rot, seedling and root infection of bottle gourd, bitter gourd and cucumber. Pak. J. Bot. 42(4): 2921-2934.

Vlasova, V. J. and N. Shitan. 1974. Means of increasing resistance of plant to Fusarium wilt NAUCHN TRUDY STRAVROOL SK 37: 127-133.

Walid, N., Mc. D. Jim and W. Steve. 2010. The Efficiency of Trichoderma harzianum and Aneurinobacillus migulanus in the Control of Gladiolus CormRot in Soil-Less Culture System. American J. of Agril. and Biolo. Sci. 5(4): 436-445.

Woltz, S.S. 1976: Fertilization of gladiolus. Gladio Grams, NAGC, No. 21: 1-5. 